Introduction: Kinesiology Taping is a method that assists healing processes and improves the physical efficiency.

The aim of the study was to assess the influence of Kinesiology Taping on the lymphoedema reduction among women after mastectomy.

Material and methods: The subject of the research included 44 women underwent single mastectomy along with the removal of lymph nodes. The examination was carried out from the $4^{\text {th }}$ of January to the $4^{\text {th }}$ of February, 2013. The traditional taping method was implemented among 22 women, whereas the own taping method was used among the other 22 women. The therapy took 21 days, during which the tapes were applied three times every 7 days. The measurements were made before every application and at the end of the therapy. In the study, a questionnaire was used and it included questions concerning basic demographic, epidemiological data as well as the evaluation of the therapy effectiveness. The linear measurements of the upper limbs, the measurements of the range of joints' motion in the upper limb were taken as well as grip strength was made.

Results: The reduction of the volume of lymphoedema of $55 \%$ was reported in the study group, whereas the oedema reduced by $27 \%$ in the clinical control one.

Conclusions: In the reduction of lymphoedema, the greater effectiveness of the own taping method in comparison to the traditional one was reported. Kinesiology Taping exerted an influence on the improvement of the upper limb's joints movability and the grip strength.

Key words: lymphoedema, Kinesiology Taping, mastectomy.

Contemp Oncol (Pozn) 2014; 18 (2): 124-129 DOI: $10.5114 /$ wo.2014.40644

\section{The influence of Kinesiology Taping on the reduction of lymphoedema among women after mastectomy - preliminary study}

Teresa Bronisława Pop ${ }^{1}$, Bożenna Karczmarek-Borowska², Monika Tymczak ${ }^{1}$, Ireneusz Hałas ${ }^{3}$, Joanna Banaś ${ }^{1}$

${ }^{1}$ Institute of Physiotherapy, University of Rzeszów, Poland

2Department of Oncology at the Faculty of Medicine, University of Rzeszów, Poland ${ }^{3}$ Voivodeship Centre of Occupational Medicine the Centre of Prevention and Healing Subsidiary Nr 2 Rehabilitation Centre, Lublin, Poland

\section{Introduction}

Kinesiology Taping is a method that constitutes an extension of the Japanese Kinesiology Taping developed by Dr Kenzo Kase, a chiropractor. The new conception is based on the contemporary achievements and the diagnostic capabilities of fascial mechanics and the arrangement of the muscular chains. The applications which were applied cause not only mechanical changes, but also sensory ones that provide a stimulus to a change in body functioning or its rebuilding. Thanks to the enlargement of the interfascial space, the microvasculature of the lymph is enhanced and consequently the flow of the lymph is improved and its quicker evacuation from the swollen limb is possible [1-3]. The tape used in Kinesiology Taping has similar properties to human skin and it enables the activation of spontaneous compensatory reactions, which greatly accelerate recovery. Among the many advantages of dynamic taping, the greatest ones are non-invasiveness, painlessness and sensory stimulation.

One of the Kinesiology Taping techniques is the lymphatic technique that can be applied while treating patients with lymphoedema. The circulation of lymph in the lymphatic vessels is facilitated thanks to the reduced pressure that is under the applied tape. In the lymphatic technique, the tapes are applied in various directions, in a spiral or crisscross way. In the standard method which is common practice, the applications start with the proximal and move towards distal parts $[1,4]$.

Women's rehabilitation after mastectomy is based on the dynamic work of muscles which loads the organism with oxygen and nutrients and removes metabolic waste products. By taking their physical and mental abilities into consideration, the methodology of exercises is fitted to individual patients. It is important to pay attention to the high position of a limb during exercises as well as during the activities of daily living [5-8].

\section{Aim of the study}

The purpose of this study was to assess the influence of Kinesiology Taping on the reduction of lymphoedema among women after mastectomy.

\section{Material and methods}

Material

The study was conducted among the patients using the randomization method. 
The own taping method was implemented in the study group including 22 women, while the other 22 women constituted the clinical control group and the traditional taping method was used among them. Women divided into groups underwent radical mastectomy or breast conserving therapy in which lymph nodes were removed. The examined women did not belong to any club such as the Amazon Club.

The study was carried out from the $4^{\text {th }}$ of January to the $4^{\text {th }}$ of February, 2013. Soft oedema occurred in all cases.

Both groups were similar in terms of age, height and body weight, as evaluated using Student's t test ( $p=0.0834)$ (Table 1). The average age of women belonging to the study group was 63; the average height was $165 \mathrm{~cm}$ and body weight was $68 \mathrm{~kg}$. Taking the clinical control group into consideration the values are as follows: $61,167 \mathrm{~cm}, 71 \mathrm{~kg}$ (Table 1). Surgical treatment was performed in 2010-2011.

Twenty women from the study group were right handed, whereas 2 women were left-handed. In the clinical control group, 17 women were right-handed and 5 were left-handed. In the study group, stage I lymphoedema occurred among 17 women, whereas stage II lymphoedema among 5. In the clinical control group, stage I lymphoedema was reported among 15 women, while stage II lymphoedema among 7 (Table 2). Radical mastectomy was done among 13 women from the study group and 15 from the clinical control group (Table 2). Supplemental radiotherapy was received by 9 women from the study group and 7 from the clinical control group (Table 2). Radiotherapy was given only to women who underwent breast conserving therapy. No woman, after the radical surgery (mastectomy with lymphadenectomy), was reported to have cancer of the lymph nodes $\geq 4$.

Eight women from the study group had right-sided mastectomy and 14 women underwent surgery on the left side. In the clinical control group, 10 examined women had right-sided mastectomy and 12 left mastectomy. The examined women belonging to both groups received chemotherapy and/or hormone therapy and radiotherapy among the women whose treatment did not require breast removal.

\section{Methods}

Women who met the following criteria took part in the examination:

1. The occurrence of stage I and II lymphoedema according to the classification of International Society of Lymphology 2003.

2. After radical mastectomy or surgery without breast removal.

3. Without skin changes or inflammation of the upper limb after the surgery.

4. Women's consent to be examined.

The criteria of exclusion from the examination:

1. Skin changes and inflammation of the upper limb after the surgery.

2. Stage III lympoedema according to the classification of International Society of Lymphology.

3. Women who did not give consent to be examined.
The following research tools were used in the examination:

1) self-prepared questionnaire that included questions concerning demographic data and the scale of subjective assessment of the therapy effects in which the examined women could choose four options: bad, average, good, or very good,

2) the linear measurements of the upper limbs,

3) the measurement of the range of joints' motion in the limb on the operated side,

4) the measurement of grip strength.

The rehabilitation programme consisted of:

1. Application of Kinesiology Taping.

2. Physical therapy - every patient received a set of 5 exercises to be practised twice a day in the morning and evening until the end of the therapy.

3. Patient's education - the patient was informed about the body and tape hygiene methods.

The therapy method of lymphoedema included the techniques of Kinesiology Taping. K-Active Tapes were used for the applications. The measurement of lymphoedema was taken in the sitting position. The upper limb was bent at $90^{\circ}$ with extension of the elbow joint. The assessment of oedema was made before the procedure. The measurement of circumference of the limb on the operated side was taken using measurement apparatus of $86 \mathrm{~cm}$ $\times 20 \mathrm{~cm}$ made by the authors (Fig. 1) and reliable results were obtained. The levels are marked on the scale every $4 \mathrm{~cm}$. The measurements were taken using measure tape and the levels are:

- $1^{\text {st }}$ level - at metacarpophalangeal joint level,

- $2^{\text {nd }}$ level - through the radio carpal joint,

- $3^{\text {rd }}$ level and more - every $4 \mathrm{~cm}$ from the sulcus carpi depending on the limb's length.

The last level - at the axilla level.

Table 1. Comparison of age and somatic features

$\begin{array}{lcc}\text { Examined feature } & \text { Study group } & \begin{array}{c}\text { Clinical } \\ \text { control group }\end{array} \\ \text { age } & ` x=63 & ` x=61 \\ \text { height } & ` x=165 \mathrm{~cm} & ` x=167 \mathrm{~cm} \\ \text { weight } & ` x=68 \mathrm{~kg} & ` x=71 \mathrm{~kg} \\ p=0.0834^{*} & & \\ \end{array}$

*Student's t-test

Table 2. Methods of treatment. Assessment of the lymphoedema

\begin{tabular}{|lcc|}
\hline Examined feature & $\begin{array}{c}\text { Study group } \\
\text { (number of } \\
\text { subjects) }\end{array}$ & $\begin{array}{c}\text { Clinical } \\
\text { control group } \\
\text { (number of } \\
\text { subjects) }\end{array}$ \\
\hline radical surgery & 13 & 15 \\
breast conserving therapy & 9 & 7 \\
\hline radiotherapy & 9 & 7 \\
$1^{\text {st }}$ degree of lymph oedema & 17 & 15 \\
$2^{\text {nd }}$ degree of lymph oedema & 5 & 7
\end{tabular}




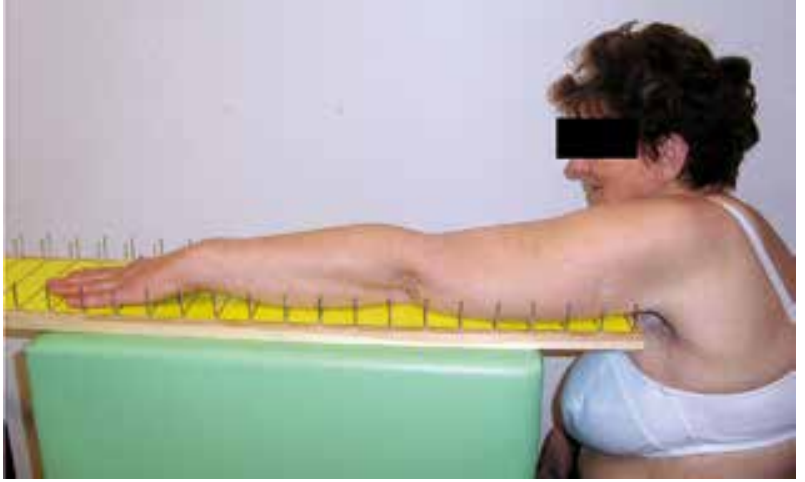

Fig. 1. Self-made measuring apparatus

The measurement of lymphoedema was made every week four times before the first application of Kinesiology Taping and after each subsequent taping. The examination was carried out four times every week. The stages of lymphoedema were ascertained by summing the particular levels of measurement every 7 days before the therapy started and Kinesiology Taping application was implemented. The circumferences measured every week were expressed as a percentage. All measurements were taken in the same conditions including patient's positions, the afternoon hours and the same point. According to Zembaty's [9] methodology, the measurement of the range of motions was made using a goniometer with accuracy of $5^{\circ}$.

The following measurements were taken:

- in the shoulder (flexion, abduction),

- in the glenohumeral joint (extension, flexion in the horizontal plane, extension in the horizontal plane, inside and outside rotation),

- in the elbow joint (flexion, extension),

- in the radio carpal joint (flexion, extension).

The grip strength was measured twice with a hand dynamometer and it was calculated in the sitting position with upper limbs that were in zero position. The measurement included the upper limb on the operated side. The better result was taken after two trials.

Kinesiology Taping technique was used in the study group as well as in the clinical control one. The therapy took 21 days. According to Kinesiology Taping technique, the tapes were applied three times every 7 days, which is in accordance with the used application technique, and the measurement was made before every application and at the end of the therapy ( $1^{\text {st }}, 2^{\text {nd }}, 3^{\text {rd }}, 4^{\text {th }}$ examination).

The own taping method was implemented in the study group. The elevation of the swollen upper limb was used before applying the tapes, which took 20 minutes. Then, the lymphatic application consisting of two parts, the spiral and directional one, was used. The spiral application was based on applying 4 tails of the tape on the entire length of the upper limb with $10 \%$ stretch. The base part of the tape which was $2 \mathrm{~cm}$ long was applied in the most distant part of the oedema. The tails of the tapes were applied at a 45-degree angle in the upper limb. Directional application consisted of the base part and 4 tails. The $2 \mathrm{~cm}$ long base part was applied without stretch of the tape. Four tails were applied with $10 \%$ stretch. The tails were applied in the

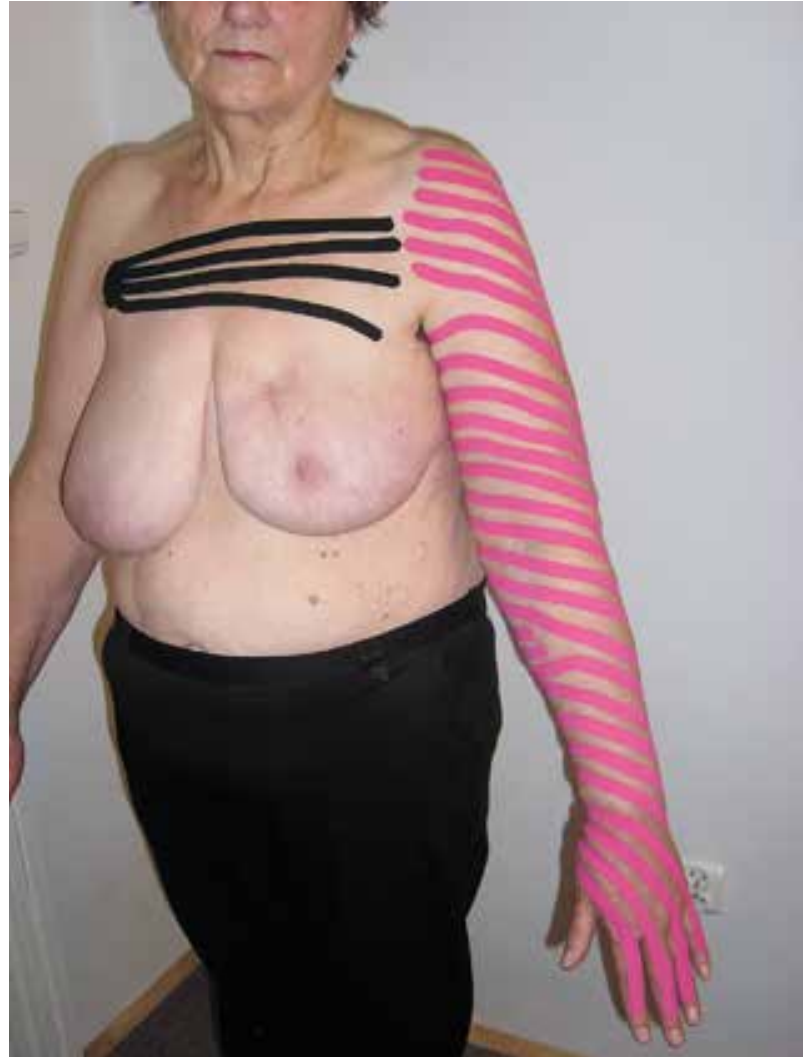

Fig. 2. The own method of taping

non-operated lymph nodes on the opposite side. The own method of applying the tape started at the most distant part of the limb, moving to the proximal one (Fig. 2).

The traditional method was implemented in the clinical control group. The application ways and the level of tail stretch were the same as in the own method. The difference lay in the direction of tape application and the lack of limb elevation. In the traditional method, the direction of application was from the proximal part of the limb to the most distant one.

\section{Statistical analysis}

Statistica 5.1. 97 edition was used to calculate the results of the study. In order to compare the particular samples of the two groups, we used Student's $t$ test in which dependent samples were calculated and ANOVA test. Non-parametric Mann-Whitney U-test was used due to the fact that not all the variables were in accordance with Gaussian distribution. Statistically significant results were presented in the tables as there were many measured parameters. In order to compare the subjective assessment of therapeutic effects (Table 3 ), the statistical analysis was performed with the $\chi^{2}$ independent test. The research was approved by the Bioethics Committee of Rzeszow University.

\section{Results}

Among the study group, the effects of the treatment were assessed by 10 women as very good, 9 as good, and 3 as average; however, 4 women from the clinical control group assessed the effects as very good. Nine women from 
the clinical control group assessed the effects as good and the average option was chosen by 9 women. No women from either group chose the option bad (Table 3). Chi-square test showed the dependency between the women's assessment of the treatment and the assigned group $(p<0.1)$.

The average reported decrease of lymphoedema was $55 \%$ in the study group and $27 \%$ in the clinical control one (Table 4). Low values $(p<0.001)$ are statistically significant according to Student's t-test and ANOVA test.

The grip strength improved by $8 \mathrm{~kg}$ in the study group after the applied therapy and by $5 \mathrm{~kg}$ in the clinical control group (Table 5). According to Student's t test and ANOVA test, the obtained results are statistically significant $(p<0.001)$.

In the study group, the mean values for shoulder flexion in the sagittal plane was $155^{\circ}$ and after the therapy it improved by $20^{\circ}$ (Table 6). The extension in the sagittal plane in the glenohumeral joint in the study group was $20^{\circ}$ and an improvement of $20^{\circ}$ was reported (Table 6). The average shoulder abduction in the study group in the horizontal plane was $150^{\circ}$. An improvement of $20^{\circ}$ after the therapy was reported (Table 6). Before the therapy, the

Table 3. Subjective assessment of therapeutic effects

\begin{tabular}{|c|c|c|}
\hline $\begin{array}{l}\text { Subjective assessment of } \\
\text { therapeutic effects }\end{array}$ & Study group & $\begin{array}{c}\text { Clinical } \\
\text { control group }\end{array}$ \\
\hline bad & 0 & 0 \\
\hline moderate & 3 & 9 \\
\hline good & 9 & 9 \\
\hline very good & 10 & 4 \\
\hline
\end{tabular}

Table 4. Assessment of lymphoedema reduction

\begin{tabular}{lcc}
$\begin{array}{l}\text { Average reduction in the } \\
\text { volume of lymphoedema }\end{array}$ & Study group & $\begin{array}{c}\text { Clinical } \\
\text { control group }\end{array}$ \\
\hline examination I & $0 \%$ & $0 \%$ \\
examination II & $32 \%$ & $18 \%$ \\
examination III & $42 \%$ & $23 \%$ \\
examination IV & $55 \%$ & $27 \%$ \\
$p<0.001^{*}$ & & \\
$p<0.001^{* *}$ & & \\
${ }^{*}$ Student's t-test \\
${ }^{*}$ ANOVA test
\end{tabular}

Table 5. Grip strength

\begin{tabular}{lcc|}
\hline Grip strength $[\mathrm{kg}]$ & Study group & $\begin{array}{c}\text { Clinical } \\
\text { control group }\end{array}$ \\
\hline examination I & 14 & 13 \\
examination II & 19 & 16 \\
examination III & 20 & 16 \\
examination IV & 22 & 18 \\
$p<0.001^{*}$ & & \\
$p<0.001^{* *}$ & & \\
${ }^{*}$ Student's t-test \\
${ }^{* *}$ ANOVA test
\end{tabular}

mean value of flexion in the glenohumeral joint in the horizontal plane was $110^{\circ}$ and after the therapy it improved by $10^{\circ}$ (Table 6$)$. In the study group, the outside rotation in the glenohumeral position before the therapy was $50^{\circ}$ and the improvement was reported as $25^{\circ}$ after the therapy (Table 6).

In the clinical control group, an average flexion improvement of $20^{\circ}$ and extension of $10^{\circ}$ in a saggital plane was reported. The abduction improved by $20^{\circ}$ in a frontal position, whereas in the horizontal plane, the flexion improved by $10^{\circ}$. The extension in the horizontal plane improved by $5^{\circ}$ and the outside rotation by $10^{\circ}$ (Table 6).

According to the Student's test and ANOVA test, the obtained results of the shoulder and glenohumeral joint movability in both groups are statistically significant (Table 6).

Table 6. Improvement in range of motion in the shoulder and glenohumeral joint

\begin{tabular}{|c|c|c|c|}
\hline Motion & & Study group & $\begin{array}{c}\text { Clinical } \\
\text { control group }\end{array}$ \\
\hline \multirow{5}{*}{$\begin{array}{l}\text { flexion in } \\
\text { the sagittal } \\
\text { plane }\end{array}$} & examination I & $155^{\circ}$ & $150^{\circ}$ \\
\hline & examination II & $160^{\circ}$ & $160^{\circ}$ \\
\hline & examination III & $170^{\circ}$ & $170^{\circ}$ \\
\hline & examination IV & $175^{\circ}$ & $170^{\circ}$ \\
\hline & therapy effect & $20^{\circ}$ & $20^{\circ}$ \\
\hline \multirow{5}{*}{$\begin{array}{l}\text { extension } \\
\text { in the } \\
\text { sagittal } \\
\text { plane }\end{array}$} & examination I & $20^{\circ}$ & $20^{\circ}$ \\
\hline & examination II & $30^{\circ}$ & $25^{\circ}$ \\
\hline & examination III & $40^{\circ}$ & $30^{\circ}$ \\
\hline & examination IV & $40^{\circ}$ & $30^{\circ}$ \\
\hline & therapy effect & $20^{\circ}$ & $10^{\circ}$ \\
\hline \multirow{5}{*}{$\begin{array}{l}\text { abduction } \\
\text { in the } \\
\text { frontal } \\
\text { plane }\end{array}$} & examination I & $150^{\circ}$ & $150^{\circ}$ \\
\hline & examination II & $160^{\circ}$ & $155^{\circ}$ \\
\hline & examination III & $165^{\circ}$ & $160^{\circ}$ \\
\hline & examination IV & $170^{\circ}$ & $170^{\circ}$ \\
\hline & therapy effect & $20^{\circ}$ & $20^{\circ}$ \\
\hline \multirow{5}{*}{$\begin{array}{l}\text { flexion } \\
\text { in the } \\
\text { horizontal } \\
\text { plane }\end{array}$} & examination I & $110^{\circ}$ & $110^{\circ}$ \\
\hline & examination II & $120^{\circ}$ & $110^{\circ}$ \\
\hline & examination III & $120^{\circ}$ & $110^{\circ}$ \\
\hline & examination IV & $120^{\circ}$ & $120^{\circ}$ \\
\hline & therapy effect & $10^{\circ}$ & $10^{\circ}$ \\
\hline \multirow{5}{*}{$\begin{array}{l}\text { extension } \\
\text { in the } \\
\text { horizontal } \\
\text { plane }\end{array}$} & examination I & $20^{\circ}$ & $20^{\circ}$ \\
\hline & examination II & $30^{\circ}$ & $20^{\circ}$ \\
\hline & examination III & $30^{\circ}$ & $20^{\circ}$ \\
\hline & examination IV & $30^{\circ}$ & $25^{\circ}$ \\
\hline & therapy effect & $10^{\circ}$ & $5^{\circ}$ \\
\hline \multirow{5}{*}{$\begin{array}{l}\text { outside } \\
\text { rotation } \\
\text { (F90) }\end{array}$} & examination I & $50^{\circ}$ & $50^{\circ}$ \\
\hline & examination II & $65^{\circ}$ & $50^{\circ}$ \\
\hline & examination III & $70^{\circ}$ & $55^{\circ}$ \\
\hline & examination IV & $75^{\circ}$ & $60^{\circ}$ \\
\hline & therapy effect & $25^{\circ}$ & $10^{\circ}$ \\
\hline
\end{tabular}

Student's t-test $-p<0.001$, ANOVA test $-p<0.001$ 
According to Student's t-test, the mean values for the range of motion with the exception of outside rotation in the glenohumeral joint are statistically significant $(p<0.05)$ between the study group and clinical control group. Statistical significance was recorded for the same parameters in the ANOVA test.

The comparative analysis of the results of the range of motion in radiocarpal and elbow joints and outside rotation in the glenohumeral joint did not show statistically significant differences between the study group and the clinical control group.

\section{Discussion}

According to Kołodziejski et al. [10] and Szuba et al. [11], lymphoedema occurs in more than 10 million people in the course of cancer, inflammation and surgical treatment. Box et al. [12] claim that the early signs of lymphoedema occur as a human's reaction to the surgical treatment and radiotherapy. They define such kind of oedema as transitory.

It was reported in the undertaken examinations that lymphoedema occurred after two years following the surgery. According to Box et al. [12], the difference of more than $1.5 \mathrm{~cm}$ in results of measurement of both upper limbs is the criterion for the diagnosis of lymphoedema. Brauer et al. [13] state that there is a possibility of making errors in the standard metric system of measurement. Hayes et al. [14] note that special attention should be paid to the constant conditions in terms of time of the day and test points in which the measurement of oedema is taken. Such conditions can be fulfilled by using the self-made apparatus for linear measurement. The self-made apparatus guarantees the reproducibility of measurements and the constant localization of test points in the examinations. Women belonging to both groups, the clinical control and the study one, were similar in terms of age, the date of mastectomy and the received postoperative treatment, and this enhanced the credibility of the conducted examination.

According to Tsai et al. [15], Kinesiology Taping is a method equally effective as lymphatic drainage and multi-layer lymphoedema bandaging. Although they did not record statistically significant differences between the two groups, they stated that Kinesiology Taping turned out to be more accepted by the patients being examined. The traditional application of tapes was used in these studies.

In the conducted studies, it was proved that the own taping method is more effective in comparison with the traditional one. It can be concluded from the presented results in the study that changing the direction of the tapes' application exerts an influence on the reduction of the volume of lymphoedema among the patients from the study group and that result is statistically significant. It was reported in each examination that the gradual reduction of oedema improved the motion of joints. A reduction of oedema was observed in the clinical control group; on the other hand, there was a minor improvement in the joint motion of the upper limb, most likely due to the slower lymph evacuation. Similar results were obtained by Lipinska et al. [16].
The upper limb elevation that was used before the application in the study group additionally activates the muscle pump. According to Gradalski et al. [17], this increases the flow of lymph 15 -fold. The previous studies conducted by Chwalczewska et al. [18] indicate that untreated lymphoedema has a progressive character and results in a decreased quality of women's life. Dziura et al. [19] emphasise the usefulness of patient's education in the lymphoedema therapy. In the obtained results, they showed that the best source of knowledge about recovery after mastectomy is not medical staff, but other patients $[6,10,19]$. The education was delivered to the patients on the first day of the study.

According to Stanisic et al. [20], the aim of the oedema-reducing therapy is to allow the patients to practise their professions again with as quick convalescence as possible. Taking subjective assessment of the patients into consideration, it was demonstrated that the method did not limit the activities of daily living. Moreover, a positive influence of the method on oedema reduction was reported by the patients.

The conducted studies prove that Kinesiology Taping exerts an enormous influence on the treatment of lymphoedema. In physiotherapy, Jeziorski [21], Andersen [22] and Johansson [23] state that it is the key element in women's therapy after mastectomy. Additionally, Moseley [24] and McKenzie [25] pay special attention to the continuity of the therapy that should be based on the follow-up treatment at home in the form of auto-therapy and prevention of lymphoedema. Effective oedema-reducing therapy has a positive influence on the quality of women's life after mastectomy [26, 27].

In order to examine the effects of the own taping method, the examination should be broadened and conducted on a larger group.

In conclusion, in the reduction of lymphoedema, the greater effectiveness of the own taping method in comparison to the traditional one was reported ( $p<0.001$ ).

Kinesiology Taping technique exerted an influence on the improvement of the upper limb joints' movability and the grip strength.

\section{The authors declare no conflict of interest.}

\section{References}

1. Hałas I. Kinesiology Taping - kurs zaawansowany. Skrypt. Lublin 2010.

2. Hałas I. Kinesiology Taping - metoda wspomagająca terapię tkanek miękkich. Prakt Fizjoter Rehabil 2010; 9: 22-5.

3. Śliwiński Z, Senderek T. Kinezjotaping - nowa metoda leczenia? Rehabil Prakt 2007; 3: 18-20.

4. Woźniewski M, Kornafel J. Rehabilitacja w onkologii. Elsevier Urban \& Partner, Wrocław 2010.

5. Mikołajewska E. Fizjoterapia po mastektomii. PZWL, Warszawa 2010.

6. Pyszora A. Kompleksowa fizjoterapia pacjentów z obrzękiem limfatycznym. Med Paliat Prakt 2010; 4: 23-9.

7. Liao S, Lee Y, Chen S, Kuo S, Liang W, Wei T, Liu M. Incidence and risk factors analysis of lymhoedema secondary to breast cancer. Tw J Phys Med Rehabil 2009; 37: 217-25. 
8. Hayes SC, Reul-Hirche H, Turner J. Exercise and secondary lymphedema: safety, potential benefits and research issues. Med Sci Sports Exerc 2009; 41: 483-9.

9. Zembaty A. Kinezyterapia. Wyd. Kasper, Kraków 2002.

10. Kołodziejski L, Łobaziewicz W, Ochałek K, Niedbałek E. Obrzęk limfatyczny kończyny górnej po radykalnym leczeniu chorych na raka piersi - aktualne zasady postępowania. Rehabil Med 2009; 13: 23-31.

11. Szuba A, Shin WS, Strauss HW, Rockson S. The third circulation: radionuclide lyphoscintigraphy in the evaluation of lymphoedema. J Nucl Med 2003; 44: 43-57.

12. Box RC, Reul-Hirche HM, Bullock-Saxton JE, Furnival CM. Physiotherapy after breast cancer surgery: results of a randomised controlled study to minimise lymphoedema. Breast Cancer Res Treat 2002; 75: 51-64.

13. Brauer WJ. Zalecenia postępowania terapeutycznego - diagnostyka i leczenie obrzęku limfatycznego. Rehabil Med 2005; 9: 59-62.

14. Hayes S, Cornish B, Newman B. Comparison of methods to diagnose lymphoedema among survivors: 6-month follow-up. Breast Cancer Res Treat 2005; 89: 221-6.

15. Tsai HJ, Hung HC, Yang JL, Huang CS, Tsauo JY. Could Kinesio tape replace the bandage in decongestive lymphatic therapy for breast-cancer-related lymphoedema? A pilot study. Support Care Cancer 2009; 17: 1353-60.

16. Lipińska A, Śliwiński Z, Kiebzak W, Senderek T, Kirenko J. Wpływ aplikacji kinesiotapingu na obrzęk limfatyczny kończyny górnej u kobiet po mastektomii. Fizjoter Pol 2007; 7: 258-69.

17. Grądalski T, Ochatek K. Podstawy patofizjologii i postępowania w obrzęku limfatycznym w chorobie nowotworowej. Nowa Med 2000; 1: 55-8.

18. Chwałczyńska A, Woźniewski M, Rożek-Mróz K, Malicka I. Jakość życia kobiet po mastektomii. Wiad Lek 2004; 57: 5-6.

19. Dziura I, Grądalski T. Wiedza o czynnikach wyzwalających powstanie obrzęku chłonnego i stosowanie się do zaleceń profilaktycznych u chorych po mastektomii. Rehabil Med 2008; 4: 23-7.

20. Stanisic M, Gabriel M, Pawlaczyk K, Snoch M, Stefaniak K. Wpływ intensywnej terapii przeciwobrzękowej na przywrócenie zdolności do pracy u chorych z zaawansowanymi postaciami obrzęków limfatycznych. Orzecznictwo Lekarskie 2007; 4: 85-92.

21. Jeziorski A. Obrzęk limfatyczny jako powikłanie leczenia chorych na raka piersi - przegląd piśmiennictwa. Onkol Pol 1999; 2: 121-5.

22. Andersen L, Højris I, Erlandsen M, Andersen J. Treatment of breast-cancer-related lymphedema with or without manual lymphatic drenaige. Acta Oncol 2000; 39: 399-405.

23. Johansson K. Is physiotherapy useful to the breast cancer patient? Acta Oncol 2005; 44: 423-4.

24. Moseley AL, Carati CJ, Piller NB. A systematic review of common conservative therapies for arm lymhoedema secondary to breast cancer treatment. Ann Oncol 2007; 18: 639-46.

25. McKenzie DC, Kalda AL. Effect of upper extremity exercise on secondary lymphedema in breast cancer patients: a pilot study. J Clin Oncol 2003; 21: 463-6.

26. Zegarski W, Głowacka I, Ostrowska Ż. Ocena jakości życia kobiet po mastektomii na podstawie standardowych kwestionariuszy QLQ-C30 i QLQ BR-23. Nowotwory 2010; 60: 532-5.

27. Zegarski W, Basałygo M. Physiotherapy assessment of the impact on quality of life after surgical treatment of breast cancer. Wspolczesna Onkol 2010; 14: 281-5.

\section{Address for correspondence}

Teresa Bronisława Pop MD, PhD

Institute of Physiotherapy

University of Rzeszów

Warszawska 26 A, 35-205 Rzeszów

tel. +48 178721920

e-mail: popter@interia.pl

Submitted: 12.12 .2013

Accepted: $\quad 18.12 .2013$ 